\title{
Select Calcium Compounds Reduce the Severity of Phytophthora Stem Rot of Soybean
}

T. Sugimoto, K. Watanabe, S. Yoshida, M. Aino, and K. Irie, Hyogo Agricultural Institute for Agriculture, Forestry and Fisheries, 1533 Minamino-oka, Befu, Kasai, Hyogo 679-0198, Japan; T. Matoh, Kyoto University, Laboratory of Plant Nutrition, Division of Applied Life Sciences, Graduate school of Agriculture, Oiwake, Kitashirakawa, Sakyo-ku, Kyoto 606-8502, Japan; and A. R. Biggs, West Virginia University, Kearneysville Tree Fruit Research and Education Center, P.O. Box 609, Kearneysville, WV 25430

\begin{abstract}
Sugimoto, T., Watanabe, K., Yoshida, S., Aino, M., Irie, K., Matoh, T., and Biggs, A. R. 2008. Select calcium compounds reduce the severity of Phytophthora stem rot of soybean. Plant Dis. 92:1559-1565.

This study investigated the effects of several calcium compounds on Phytophthora stem rot of soybean (Glycine max) and fungal growth and zoospore release of a Phytophthora sojae isolate in vitro. All concentrations of five formulated calcium products $\left[\mathrm{Ca}(\mathrm{COOH})_{2}-\mathrm{A}, \mathrm{Ca}(\mathrm{COOH})_{2}-\mathrm{B}\right.$, $\mathrm{Ca}(\mathrm{COOH})_{2}-\mathrm{C}, \mathrm{CaSO}_{4}-\mathrm{A}$, and $\left.\mathrm{CaCl}_{2}-\mathrm{A}\right]$ and two chemical compounds $\left[\mathrm{CaCl}_{2}\right.$ and $\left.\mathrm{Ca}\left(\mathrm{NO}_{3}\right)_{2}\right]$ applied prior to inoculation significantly suppressed disease incidence. Among all the products and chemicals, $\mathrm{Ca}(\mathrm{COOH})_{2}$-A was the most effective in suppressing the incidence of disease. In most cases, no significant relationship was observed between inhibition of growth rate in vitro and disease reduction in growth chamber tests. Therefore, disease suppression recorded in laboratory experiments using pathogen mycelium was likely due to the responses of plant tissues rather than the direct inhibition of pathogen fungal growth by the calcium compounds. The extent of disease reduction was related to increased calcium uptake by plants, suggesting that calcium was the effective element in reducing Phytophthora stem rot. Seedling tray experiments using zoospores indicated that the application of $10 \mathrm{mM} \mathrm{Ca}(\mathrm{COOH})_{2}-\mathrm{A}$ was more effective for reducing incidence of disease under growth chamber conditions, compared to other concentrations. The presence of 4 to $20 \mathrm{mM}$ of all seven calcium solutions decreased the release of zoospores, although $0.4 \mathrm{mM}$ of all compounds significantly increased zoospore release. Therefore, disease reduction in the growth-chamber experiments was due to the multiple effects of direct suppression on zoospore release and fungal growth in combination with the response of the host plant tissue to $\mathrm{Ca}(\mathrm{COOH})_{2}$-A.
\end{abstract}

Additional keywords: calcium chloride, calcium formate, calcium nitrate, calcium sulfate, induced resistance

Phytophthora stem rot disease, caused by the oomycete soilborne fungus Phytophthora sojae (14), is an important disease of soybean (Glycine max (L.) Merr.) around the world. It was first reported in the United States from Indiana and Ohio in 1951. This disease is most associated with slowly drained soils with high clay content, and in fields subjected to temporary flooding and ponding. $P$. sojae causes preand post-emergence damping-off, stem and root rot, and consequently wilting and death of soybean plants (9). This pathogen has aggressive and race-specific pathogenicity to soybean and causes no or few symptoms on other hosts $(14,34)$. Since 1955 , at least 55 races of $P$. sojae have been reported (8). Thus, $P$. sojae has been

Corresponding author: Takuma Sugimoto E-mail: Takuma_Sugimoto@pref.hyogo.lg.jp

Accepted for publication 1 August 2008.

doi:10.1094/PDIS-92-11-1559

(C) 2008 The American Phytopathological Society widespread in several soybean-producing areas in Asia, Africa, Europe, Canada, and the United States (25). The yields of soybean and the income of soybean producers have been decreasing considerably because of this disease (39). It was estimated that the yield suppression due to this disease during 2005 was valued at $\$ 251.6$ million $(\$ 236 / t)$ in the United States (39).

In Japan, Phytophthora stem rot disease was first observed in 1977 in Hokkaido (34), and later in other areas (30). Sugimoto et al. (30) reported that at least 15 races of $P$. sojae exist in Japan. G. max cv. Chusei-Hikarikuro, which is one of the most famous commercial black soybean cultivars produced in Japan and fetches a higher market price than yellow soybeans, is very susceptible to this pathogen $(27,34)$. Black soybeans are reported to have many positive effects on human health (32) and thus are widely planted and valuable in Japan.

For the past 40 years, control of Phytophthora stem rot has been achieved through variety selection, including the development of resistant or partially resis- tant (tolerant) cultivars of soybean $(7,30,31)$, chemical fungicides (2), soil drainage (24), and tillage practices (38). However, $P$. sojae has adapted to specific Rps (resistant to Phytophthora sojae) genes by generating new races (13). Single Rps genes have been effective for 8 to 15 years, depending on inoculum density and environmental conditions (24). Commercial applications of the fungicide metalaxyl (Ridomil and Subdue) might be effective in the short term, but the likelihood of resistance development could lead to loss of disease control (12). Sporangia formation from Phytophthora megasperma Drechs. isolate (race 3) recovered from soybean was insensitive to metalaxyl at 10 $\mu \mathrm{m} / \mathrm{ml}$ (12). It is essential to construct alternative disease management strategies, which include physical control and induction of resistance as well as chemical prophylaxis and the breeding of new resistant cultivars.

Many studies already have demonstrated the mitigating effect of the application of plant nutrients on disease management. Several inorganic elements had a suppressive effect on Phytophthora spp. $(5,26,33,35,37)$. It was previously reported that the application of $\mathrm{CaCl}_{2}$ and $\mathrm{Ca}\left(\mathrm{NO}_{3}\right)_{2}$ dramatically suppressed disease incidence caused by $P$. sojae in black soybean (cv. Chusei-Hikarikuro) and white soybean (cv. Sachiyutaka) under laboratory conditions, and affected plant resistance to the pathogen (27). The extent of disease reduction was related to increased calcium uptake by plants of the two cultivars. Further investigation is required to discover effective calcium products or compounds in reducing Phytophthora stem rot disease and to refine the amounts that could be effective in planned field trials.

Another alternative disease management strategy is related to interference with zoospore production or zoospore behavior. $P$. sojae is one of the homothallic species that produces large numbers of oospores in infected soybean tissues (24). The oospores can produce numerous, motile zoospores that initiate further cycles of disease (24). The presence of 4 to $30 \mathrm{mM} \mathrm{CaCl} 2$ and $\mathrm{Ca}\left(\mathrm{NO}_{3}\right)_{2}$ decreased the release of zoospores from isolates, although $0.4 \mathrm{mM}$ $\mathrm{CaCl}_{2}$ and $\mathrm{Ca}\left(\mathrm{NO}_{3}\right)_{2}$ significantly induced zoospore release (27). To potentially take 
advantage of this strategy, the effects of several calcium compounds on the release of zoospores should be examined to determine the most effective concentrations.

In this study, five commercial calcium products (three calcium formate formulations, including: Suicaru, hereafter referred to as $\mathrm{Ca}(\mathrm{COOH})_{2}-\mathrm{A}$; Baicaruty, hereafter referred to as $\mathrm{Ca}(\mathrm{COOH})_{2}$-B; and Hicaruku, hereafter referred to as $\mathrm{Ca}(\mathrm{COOH})_{2}{ }^{-}$ C [Koei Chemical, Nagoya, Japan]; CellBine, hereafter referred to as $\mathrm{CaSO}_{4}$-A [Shiraishi Calcium, Tokyo, Japan]; and Kalklon, hereafter referred to as $\mathrm{CaCl}_{2}-\mathrm{A}$ [Nisso Green, Tokyo, Japan]) developed in Japan were selected because of their high calcium concentrations (Table 1).

The objectives of this study were to (i) compare the efficacy of five commercial calcium products on disease reduction of cv. Chusei-Hikarikuro (black soybean), and on the growth rate and zoospore release of $P$. sojae, (ii) measure calcium concentrations in soybean seedlings after treatment with calcium compounds under laboratory conditions, and (iii) confirm the effect of selected calcium compounds on the reduction of disease incidence under growth-chamber conditions. This is the first report concerning the relationship among varying levels of commercial calcium products and Phytophthora stem rot disease on soybean.

\section{MATERIALS AND METHODS}

Pathogen and host characteristics. In 2004, 23 isolates of $P$. sojae were collected from infected soybean plants obtained from several soybean-producing fields in Japan. These isolates were examined for pathogenicity using a virulence test $(27,29)$ on G. max cv. ChuseiHikarikuro (black soybean, provided by the Tokachi Federation of Agricultural Cooperatives in Hokkaido, Japan). The virulence evaluations of isolates were per- formed using the agar medium inoculation method $(27,29)$ as described previously, which is a modification of the hypocotyl inoculation method (7). One isolate (PJ$\mathrm{H} 30$; race E) (30) was chosen because it showed highly aggressive growth on $\mathrm{cv}$. Chusei-Hikarikuro $(100 \%$ disease incidence). The cultivar Chusei-Hikarikuro and isolate PJ-H30 were used for all experiments in this study.

Effects of select calcium compounds on disease caused by $\boldsymbol{P}$. sojae. Seven calcium compounds were used in this study (Table 1). The pH of all supplemented solutions was determined in preparations that were not autoclaved. The modified agar medium inoculation method (28) was used to assess the effect of seven calcium compounds on Phytophthora stem rot disease under laboratory conditions. Briefly, eight soybean seeds (surface sterilized with $\mathrm{NaOCl}$ ) were placed on autoclaved $0.7 \%$ water agar medium $(130 \mathrm{ml}$ total volume) containing $1.0 \%(\mathrm{wt} / \mathrm{vol})$ sucrose and various concentrations $(0,0.4,4,10$, and $20 \mathrm{mM}$ ) of the seven calcium compounds listed in Table 1, where the $\mathrm{pH}$ was adjusted to 5.8 with $0.1 \mathrm{M} \mathrm{NaOH}$ in a test bottle with eight seeds per bottle. An agar medium containing only $1.0 \%$ sugar was also used as a control. The test bottles were incubated at $23^{\circ} \mathrm{C}$.

Inoculation using PJ-H30 mycelium cultured on potato dextrose agar (PDA) medium was performed under the same conditions as the pathogenic test described above. Briefly, after the first primary leaf appeared, approximately 10 days after sowing, the stem of the soybean near ground level was covered with two 3-mmdiameter plugs of 10-day-old mycelium of $P$. sojae isolate cultured on diluted PDA (2.7 g potato dextrose powder, $15 \mathrm{~g}$ sugar, and $10 \mathrm{~g}$ agar per liter of distilled water) (Nissui, Tokyo, Japan). The number of dead and surviving plants in each bottle was recorded daily for the 20-day experiment. Disease incidence was calculated after the 7th day (when the first evaluation was recorded; equivalent to the time of evaluation of the growth rate of $\mathrm{PJ}-\mathrm{H} 30$ isolate in subsequent experiments) and the 20th day (when the final evaluation was recorded) following inoculation. The ratio of dead plants to the initial eight seedlings in each bottle was calculated. Noninoculated controls also were tested under the same conditions. During the disease experiments, branching and leaf burn on soybean seedlings were measured in each bottle 20 days after inoculation. The bioassays using PJ-H30 mycelium were conducted four times in three replications, with four bottles for each calcium concentration.

Growth rate of isolate PJ-H30 on PDA containing calcium compounds. Experiments on the effects of calcium on the growth rate of $P$. sojae were conducted according to previously reported methods $(27,28)$. Briefly, isolate $\mathrm{PJ}-\mathrm{H} 30$ was grown on $15 \mathrm{ml}$ of PDA medium at $23^{\circ} \mathrm{C}$ for 10 days. Mycelial plugs (3 $\mathrm{mm}$ diameter) were transferred to another $15 \mathrm{ml}$ of PDA medium containing seven calcium compounds listed in Table 1, where the $\mathrm{pH}$ was adjusted to 5.8. After 7 days of incubation at $23^{\circ} \mathrm{C}$, the diameter of the isolate was measured on each medium. The growth rate test of the isolate was conducted three times in two replications, with four dishes at each different concentration for each calcium compound.

Relationship between calcium concentrations in soybean plants and disease incidence. Eight noninoculated seedlings were treated with a range of calcium treatments, and tissues were assayed for calcium concentration. Each calcium treatment was conducted in a test bottle using the same method as the previous experiment (described above). Briefly,

Table 1. Several concentrations of seven calcium compounds used in this study

\begin{tabular}{|c|c|c|c|c|c|c|c|c|}
\hline \multirow[b]{3}{*}{$\begin{array}{l}\text { Treatment } \\
\text { (prod. name) }\end{array}$} & \multirow[b]{3}{*}{ Manufacture } & \multirow{3}{*}{$\begin{array}{c}\text { Chemical } \\
\text { compounds } \\
\text { in treatment }\end{array}$} & \multirow[b]{3}{*}{$\begin{array}{l}\text { Calcium } \\
\text { content }(\%)\end{array}$} & \multirow{3}{*}{$\begin{array}{c}\text { Optimum } \\
\text { application } \\
\text { rate }(\mathrm{mg} / \text { /liter })^{\mathrm{z}}\end{array}$} & \multicolumn{4}{|c|}{ Trials } \\
\hline & & & & & $0.4 \mathrm{mM}$ & $4 \mathrm{mM}$ & $10 \mathrm{mM}$ & $20 \mathrm{mM}$ \\
\hline & & & & & \multicolumn{4}{|c|}{$\begin{array}{c}\text { Concentration of Ca nutrient (mg/liter) } \\
\text { ( } \mathrm{pH} \text { in calcium solution) }\end{array}$} \\
\hline $\begin{array}{l}\mathrm{Ca}(\mathrm{COOH})_{2}-\mathrm{A} \\
\text { (Suicaru) }\end{array}$ & $\begin{array}{l}\text { Koei Chemical, } \\
\text { Nagoya, Japan }\end{array}$ & $\begin{array}{l}99.8 \% \text { of } \mathrm{Ca}(\mathrm{COOH})_{2} \\
+0.2 \% \text { water }\end{array}$ & 30.0 & $1,000-2,000$ & $\begin{array}{c}53.3 \\
(5.78)\end{array}$ & $\begin{array}{c}533 \\
(6.33)\end{array}$ & $\begin{array}{l}1,333 \\
(6.68)\end{array}$ & $\begin{array}{l}2,665 \\
(6.94)\end{array}$ \\
\hline $\begin{array}{l}\mathrm{Ca}(\mathrm{COOH})_{2}-\mathrm{B} \\
\text { (Baicaruty) }\end{array}$ & $\begin{array}{l}\text { Koei Chemical, } \\
\text { Nagoya, Japan }\end{array}$ & $\begin{array}{l}90 \% \text { of } \mathrm{Ca}(\mathrm{COOH})_{2} \\
+10 \% \text { calcium } \\
\text { lignine sulfonate }\end{array}$ & 24.3 & 1,000 & $\begin{array}{c}65.9 \\
(5.65)\end{array}$ & $\begin{array}{c}659 \\
(6.00)\end{array}$ & $\begin{array}{l}1,647 \\
(6.06)\end{array}$ & $\begin{array}{l}3,294 \\
(6.08)\end{array}$ \\
\hline $\begin{array}{l}\mathrm{Ca}(\mathrm{COOH})_{2}-\mathrm{C} \\
\text { (Hicaruku) }\end{array}$ & $\begin{array}{r}\text { Koei Chemical, } \\
\text { Nagoya, Japan }\end{array}$ & $\begin{array}{l}90 \% \text { of } \mathrm{Ca}(\mathrm{COOH})_{2} \\
+10 \% \mathrm{~B}_{2} \mathrm{O}_{5}\end{array}$ & 26.4 & 1,000 & $\begin{array}{c}60.6 \\
(5.69)\end{array}$ & $\begin{array}{c}606 \\
(6.31)\end{array}$ & $\begin{array}{l}1,515 \\
(6.54)\end{array}$ & $\begin{array}{l}3,030 \\
(6.65)\end{array}$ \\
\hline $\begin{array}{l}\mathrm{CaSO}_{4}-\mathrm{A} \\
\text { (Cell-Bine) }\end{array}$ & $\begin{array}{l}\text { Shiraishi Calcium, } \\
\text { Tokyo, Japan }\end{array}$ & $\begin{array}{l}57 \% \text { of } \mathrm{CaSO}_{4} \\
+27 \% \mathrm{CaO}\end{array}$ & 32.5 & $1,250-2,500$ & $\begin{array}{c}64.0 \\
(5.70)\end{array}$ & $\begin{array}{c}640 \\
(6.38)\end{array}$ & $\begin{array}{l}1,600 \\
(7.16)\end{array}$ & $\begin{array}{l}3,200 \\
(7.45)\end{array}$ \\
\hline $\begin{array}{l}\mathrm{CaCl}_{2}-\mathrm{A} \\
\text { (Kalkon) }\end{array}$ & $\begin{array}{l}\text { Nisso Green, } \\
\text { Tokyo, Japan }\end{array}$ & $72 \%$ of $\mathrm{CaCl}_{2}$ & 26.0 & $1,429-5,000$ & $\begin{array}{c}61.6 \\
(5.43)\end{array}$ & $\begin{array}{l}616 \\
(6.10)\end{array}$ & $\begin{array}{l}1,541 \\
(7.60)\end{array}$ & $\begin{array}{l}3,081 \\
(8.96)\end{array}$ \\
\hline $\mathrm{CaCl}_{2}$ & $\begin{array}{l}\text { Nacalai Tesque, } \\
\text { Inc., Kyoto, Japan }\end{array}$ & $\mathrm{CaCl}_{2} \cdot 2 \mathrm{H}_{2} \mathrm{O}$ & 27.2 & 588 & $\begin{array}{c}58.8 \\
(5.35)\end{array}$ & $\begin{array}{c}588 \\
(5.49)\end{array}$ & $\begin{array}{l}1,471 \\
(5.68)\end{array}$ & $\begin{array}{l}2,942 \\
(5.78)\end{array}$ \\
\hline $\mathrm{Ca}\left(\mathrm{NO}_{3}\right)_{2}$ & $\begin{array}{l}\text { Nacalai Tesque, } \\
\text { Inc., Kyoto, Japan }\end{array}$ & $\mathrm{Ca}(\mathrm{NO} 3)_{2} \cdot 4 \mathrm{H}_{2} \mathrm{O}$ & 16.9 & 944 & $\begin{array}{c}94.4 \\
(5.44)\end{array}$ & $\begin{array}{c}944 \\
(5.53)\end{array}$ & $\begin{array}{l}2,362 \\
(5.54)\end{array}$ & $\begin{array}{l}4,727 \\
(5.57)\end{array}$ \\
\hline
\end{tabular}

${ }^{y}$ Chemical compounds contained in each treatment.

${ }^{\mathrm{z}}$ Optimum application rates are from production manuals. 
eight soybean seeds (surface sterilized with $\mathrm{NaOCl}$ ) for each treatment were placed on an autoclaved $0.7 \%$ water agar medium (130 ml total volume) containing $1.0 \%(\mathrm{wt} / \mathrm{vol})$ sucrose and several levels $(0,0.4,4,10$, and $20 \mathrm{mM})$ of seven calcium compounds (Table 1$)(\mathrm{pH}=5.8)$ in a test bottle (diameter $=8 \mathrm{~cm}$, height $=20$ $\mathrm{cm}$ ) with eight seeds per bottle, and incubated at $23^{\circ} \mathrm{C}$. The measurement of calcium content in the shoot was performed according to the previous report $(27,28)$. The measurement of calcium content in the shoots was conducted four times in two replications, with four bottles at each calcium concentration for each calcium compound.

Effect of seven calcium compounds on zoospore release by isolate $\mathrm{PJ}-\mathrm{H} 30$. Examination of $P$. sojae (PJ-H30) zoospores and their response to calcium treatments was performed according to previous reports $(27,28)$. Briefly, isolate PJ-H30 was grown on $15 \mathrm{ml}$ of PDA and Lima Bean agar (LBA) (Becton, Dickinson Co., Sparks, MD). Five milliliters of test solution $(0,0.4,4,10$, and $20 \mathrm{mM})$ of seven calcium compounds (Table 1$)(\mathrm{pH}=5.8)$ was poured into a petri dish $(5 \mathrm{~cm}$ diameter) containing four pieces of each agar plug and incubated at $21^{\circ} \mathrm{C}$ in darkness. The number of zoospores in the suspension was recorded according to the method previously reported (27). Zoospores from $P$. sojae were counted five times in three replications, with three dishes at each concentration.

Effect of $\mathrm{Ca}(\mathrm{COOH})_{2}$-A on disease incidence caused by $P$. sojae zoospore suspension. Ten soybean seeds were placed on autoclaved vermiculite in a 10 -well seedling tray (cell size $4 \times 4 \times 5 \mathrm{~cm}$ ) with one seed per cell. The seedling tray with 10 seeds was put on a large plastic tray to maintain soil moisture. Five days after the sowing of seeds, the seedlings were treated with $1,000 \mathrm{ml}$ of various concentrations $(0$, $0.4,4,10$, and $20 \mathrm{mM})$ of $\mathrm{Ca}(\mathrm{COOH})_{2}-\mathrm{A}$ $(\mathrm{pH}=5.8)$ per tray, and incubated at $23^{\circ} \mathrm{C}$ in the same growth chamber as the previous disease experiments. At 10 days after the sowing of seeds, the 10 soybean seedlings in each tray were inoculated with 5 $\mathrm{ml}$ each of inoculum suspension of zoospores $\left(1 \times 10^{3} / \mathrm{ml}\right)$ from the PJ-H30 isolate. Zoospores were produced using sterile distilled water (SDW) as previously described. Inoculated plants were kept under wet conditions for 2 days to enhance disease development. Seven days after inoculation, the seedlings were flooded again with $500 \mathrm{ml}$ of calcium solution per tray. Later that day and afterward, seedlings were flood-irrigated every 5 days with $1,000 \mathrm{ml}$ of SDW. Disease incidence was measured every day for the 20-day experiment, and evaluated after the 7th day and 20th day following inoculation. It was calculated as the ratio of dead plants to the initial 10 seedlings in each seedling tray.
Noninoculated controls also were tested under the same conditions. The bioassays were conducted three times in three replications, with four seedling trays at each different concentration.

Effect of $\mathrm{Ca}(\mathrm{COOH})_{2}$-A on plant height of soybean seedlings. During the disease experiments, the plant height in each tray was measured 10 days after the sowing of seeds (at the time of inoculation) and 7 days after inoculation from the ground level to the top of the plant. The measurements were conducted three times in three replications, with four seedling trays at each different concentration.

Statistical analysis. All results were analyzed by analysis of variance (ANOVA) and Fisher's least significant differences (LSD) test using Microsoft Excel software for Macintosh.

\section{RESULTS}

Effects of select calcium compounds on disease caused by $P$. sojae. Noninoculated soybean plants grew well in each treatment. The incidence of disease displayed by control soybean plants of $\mathrm{cv}$. Chusei-Hikarikuro was $58.5 \%$ (7 days after inoculation) and 100\% (20 days after inoculation) (Fig. 1). The application of seven calcium compounds resulted in sup- pression at the initial stage (until 4 days after inoculation) of infection, and the amount of disease reduction was affected by the calcium concentration in the medium.

Concentrations of $0.4,4,10$, and $20 \mathrm{mM}$ $\mathrm{Ca}(\mathrm{COOH})_{2}$-A strongly reduced disease incidence $(P<0.05)$. When the same concentrations of $\mathrm{Ca}(\mathrm{COOH})_{2}$-B were applied, the incidence of disease significantly decreased $(P<0.05)$. Although a concentration of 0.4 to $10 \mathrm{mM} \mathrm{Ca}(\mathrm{COOH})_{2}-\mathrm{C}$ was also effective in suppressing the incidence of disease, the disease incidence at $20 \mathrm{mM}$ $\mathrm{Ca}(\mathrm{COOH})_{2}-\mathrm{C}$ was not measured. The soybean plants branched poorly when 20 $\mathrm{mM} \mathrm{Ca}(\mathrm{COOH})_{2}-\mathrm{C}$ was applied; plant growth was suppressed by the higher concentration. Furthermore, leaf burn (marginal chlorosis and necrosis) was observed on the soybean seedling treated with 10 to $20 \mathrm{mM} \mathrm{Ca}(\mathrm{COOH})_{2}-\mathrm{C}$. Although $0.4 \mathrm{mM}$ $\mathrm{CaSO}_{4}$-A (Cell-Bine) did not show an effect on disease suppression 20 days after inoculation (disease incidence $=70.0 \%$ ), concentrations of 4,10 , and $20 \mathrm{mM}$ $\mathrm{CaSO}_{4}$-A were effective. All levels of $\mathrm{CaCl}_{2}$-A (Kalklon) decreased the incidence of disease. When two chemical compounds of $\mathrm{CaCl}_{2}$ and $\mathrm{Ca}\left(\mathrm{NO}_{3}\right)_{2}$ were applied as controls, the incidence of disease was re-
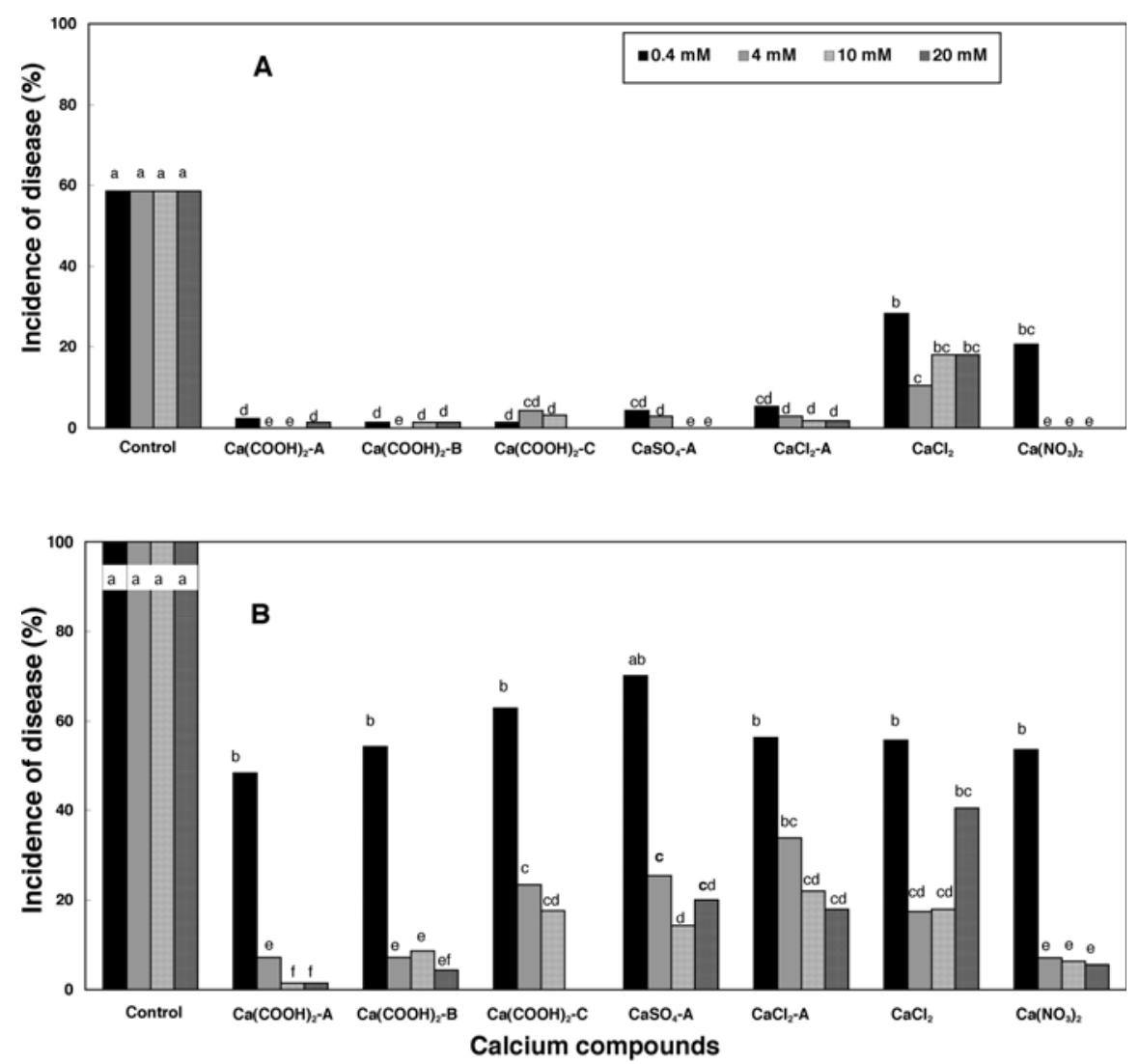

Fig. 1. Effect of various concentrations $(0,0.4,4,10$, and $20 \mathrm{mM})$ of seven calcium compounds on the incidence of disease in black soybeans, $\mathbf{A}, 7$ days, and $\mathbf{B}, 20$ days after inoculation. $\mathrm{Ca}(\mathrm{COOH})_{2}-\mathrm{A}$, $\mathrm{Ca}(\mathrm{COOH})_{2}-\mathrm{B}, \mathrm{Ca}(\mathrm{COOH})_{2}-\mathrm{C}, \mathrm{CaSO}_{4}-\mathrm{A}$, and $\mathrm{CaCl}_{2}-\mathrm{A}$ indicate $99.8 \% \mathrm{Ca}(\mathrm{COOH})_{2}+0.2 \%$ water, $90 \% \mathrm{Ca}(\mathrm{COOH})_{2}+10 \%$ calcium lignine sulfonate, $90 \% \mathrm{Ca}(\mathrm{COOH})_{2}+10 \% \mathrm{~B}_{2} \mathrm{O}_{5}, 57 \% \mathrm{CaSO}_{4}+$ $27 \% \mathrm{CaO}$, and $72 \% \mathrm{CaCl}_{2}$, respectively. Incidence of disease at $20 \mathrm{mM} \mathrm{Ca}(\mathrm{COOH})_{2}-\mathrm{C}$ was not shown, because this concentration was phytotoxic to soybean plants. Different letters denote significant differences according to ANOVA and least significant difference $(P<0.05)$. 
duced by the same concentration of calcium in comparison with controls.

Growth rate of isolate $\mathrm{PJ}-\mathrm{H} 30$ on PDA containing calcium compounds. The growth rate of PJ-H30 on PDA was affected by various concentrations $(0,0.4$, 4,10 , and $20 \mathrm{mM}$ ) of seven calcium compounds (Fig. 2). The diameter of the isolate was increased in the presence of 0.4 and $4 \mathrm{mM}$ of all seven calcium compounds in comparison with the control $(P$ $<0.05$ ), except for $0.4 \mathrm{mM} \mathrm{CaCl} 2$. Furthermore, 10 to $20 \mathrm{mM} \mathrm{CaSO}_{4}-\mathrm{A}$ and 10 $\mathrm{mM} \mathrm{Ca}\left(\mathrm{NO}_{3}\right)_{2}$ slightly increased fungal growth. However, fungal growth was suppressed significantly $(P<0.05)$ when 10 to $20 \mathrm{mM} \mathrm{Ca}(\mathrm{COOH})_{2}-\mathrm{A}$, $\mathrm{Ca}(\mathrm{COOH})_{2}-\mathrm{B}$, and $\mathrm{Ca}(\mathrm{COOH})_{2}-\mathrm{C}$ were applied. Concentrations of 10 to $20 \mathrm{mM}$ $\mathrm{CaCl}_{2}$-A and $20 \mathrm{mM} \mathrm{CaCl}_{2}$ slightly reduced the growth of the isolate. Therefore, $\mathrm{Ca}(\mathrm{COOH})_{2}-\mathrm{A}, \mathrm{Ca}(\mathrm{COOH})_{2}-\mathrm{B}$, and $\mathrm{Ca}(\mathrm{COOH})_{2}-\mathrm{C}$ were more effective than the other four calcium compounds in reducing fungal growth.

Relationship between calcium concentrations in soybean plants and disease incidence. The noninoculated soybean plants grew well in each treatment. There was a difference in shoot dry weight at the time of inoculation when using different concentrations of seven calcium compounds (Table 2). Application of 4 to 20 $\mathrm{mM}$ of the seven compounds increased the growth of shoots compared with the control plants. Calcium concentration (\% of dry weight) in shoots was correlated with the concentration in the agar medium: $r=$ $0.863\left[\mathrm{Ca}(\mathrm{COOH})_{2}-\mathrm{A}\right], 0.924\left[\mathrm{Ca}(\mathrm{COOH})_{2^{-}}\right.$ $\mathrm{B}], 0.915\left(\mathrm{CaSO}_{4}-\mathrm{A}\right), 0.886\left(\mathrm{CaCl}_{2}-\mathrm{A}\right)$, $0.955\left(\mathrm{CaCl}_{2}\right)$, and $0.959 \quad\left[\mathrm{Ca}\left(\mathrm{NO}_{3}\right)_{2}\right]$. However, the calcium concentration was not correlated with the concentration in the medium $\mathrm{Ca}(\mathrm{COOH})_{2}-\mathrm{C} \quad(r=0.458)$. $\mathrm{Ca}\left(\mathrm{NO}_{3}\right)_{2}$ was the most effective of the seven calcium compounds for increasing

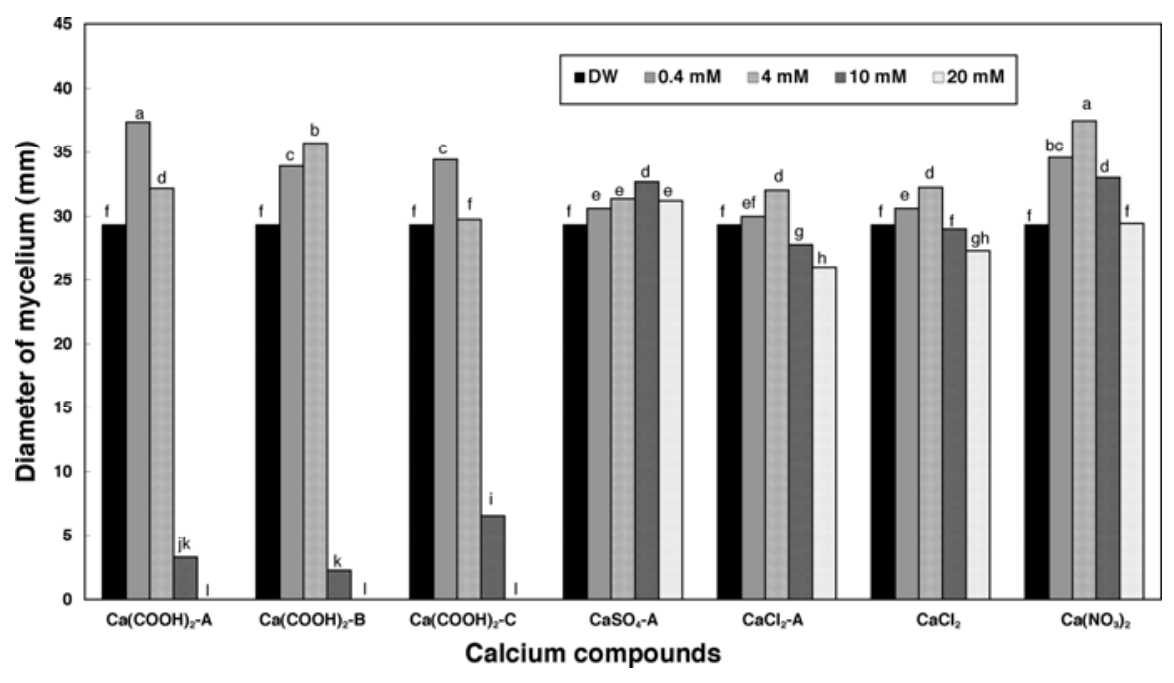

Fig. 2. Effect of various concentrations $(0,0.4,4,10$, and $20 \mathrm{mM})$ of seven calcium compounds on growth rate of Phytophthora sojae isolate PJ-H30 after 7 days incubation at $23^{\circ} \mathrm{C} . \mathrm{Ca}(\mathrm{COOH})_{2}-\mathrm{A}$, $\mathrm{Ca}(\mathrm{COOH})_{2}-\mathrm{B}, \mathrm{Ca}(\mathrm{COOH})_{2}-\mathrm{C}, \mathrm{CaSO}_{4}-\mathrm{A}$, and $\mathrm{CaCl}_{2}-\mathrm{A}$ indicate $99.8 \% \mathrm{Ca}(\mathrm{COOH})_{2}+0.2 \%$ water, $90 \% \mathrm{Ca}(\mathrm{COOH})_{2}+10 \%$ calcium lignine sulfonate, $90 \% \mathrm{Ca}(\mathrm{COOH})_{2}+10 \% \mathrm{~B}_{2} \mathrm{O}_{5}, 57 \% \mathrm{CaSO}_{4}+$ $27 \% \mathrm{CaO}$, and $72 \% \mathrm{CaCl}_{2}$, respectively. Incidence of disease at $20 \mathrm{mM} \mathrm{Ca}(\mathrm{COOH})_{2}-\mathrm{C}$ was not shown, because this concentration was phytotoxic to soybean plants. Different letters denote significant differences according to ANOVA and least significant difference $(P<0.05)$. calcium concentration in the plant tissue (Table 2).

Disease reduction (20 days after inoculation) was related to increased calcium uptake by the shoots, except when the amount of calcium applied as $\mathrm{CaCl}_{2}$ or $\mathrm{CaSO}_{4}$-A was more than $0.275 \%\left(\mathrm{CaCl}_{2}\right)$ or $0.334 \%\left(\mathrm{CaSO}_{4}-\mathrm{A}\right)$ of the shoot dry weight (Fig. 3).

Effect of seven calcium compounds on zoospore release by isolate $\mathrm{PJ}-\mathrm{H} 30$. Zoospore release from isolate $\mathrm{PJ}-\mathrm{H} 30$ cultured on PDA did not occur under any concentrations of seven calcium compounds or in SDW (data not shown). However, zoospore release from the isolate on LBA was influenced greatly by various concentrations of the seven calcium solutions (Fig. 4). Although $0.4 \mathrm{mM}$ of seven calcium compounds increased zoospore release, concentrations of 4 to $20 \mathrm{mM} \mathrm{Ca}(\mathrm{COOH})_{2}$-A, $\mathrm{Ca}(\mathrm{COOH})_{2}-\mathrm{B}, \mathrm{Ca}(\mathrm{COOH})_{2}-\mathrm{C}, \mathrm{CaCl}_{2}$, and $\mathrm{Ca}\left(\mathrm{NO}_{3}\right)_{2}$ significantly reduced the release of zoospores $(P<0.05)$. These results indicate that $\mathrm{Ca}(\mathrm{COOH})_{2}$ was more effective for the inhibition of zoospore release compared with the other calcium compounds (Fig. 4).

Effect of $\mathrm{Ca}(\mathrm{COOH})_{2}$-A on disease incidence caused by $P$. sojae zoospore suspension. $\mathrm{Ca}(\mathrm{COOH})_{2}-\mathrm{A}$ was selected for the disease experiment using zoospore suspension, because $\mathrm{Ca}(\mathrm{COOH})_{2}$-A markedly reduced incidence of disease under laboratory conditions (Fig. 1). Furthermore, $\mathrm{Ca}(\mathrm{COOH})_{2}$-A was effective for inhibiting growth rate and zoospore release of P. sojae (Figs. 2 and 4). All levels of $\mathrm{Ca}(\mathrm{COOH})_{2}$-A decreased the incidence of disease at 7 days and 20 days after inoculation, compared with the controls (Table 3).

Effect of $\mathrm{Ca}(\mathrm{COOH})_{2}-\mathrm{A}$ on plant height of soybean seedlings. There were no differences in plant height at the time of inoculation when using different concentrations of $\mathrm{Ca}(\mathrm{COOH})_{2}-\mathrm{A}$ (Table 3). Although application of 4 to $10 \mathrm{mM}$ $\mathrm{Ca}(\mathrm{COOH})_{2}-\mathrm{A}$ increased plant height compared with the control plants 7 days after inoculation, the $20 \mathrm{mM}$ amendment slightly suppressed plant growth.

Table 2. Effect of calcium concentration on shoot dry weight and calcium concentration in noninoculated black soybean plants ${ }^{y}$

\begin{tabular}{|c|c|c|c|c|c|c|c|}
\hline $\begin{array}{l}\text { Concentration } \\
(\mathbf{m M})\end{array}$ & $\mathrm{Ca}(\mathrm{COOH})_{2}-\mathrm{A}$ & $\mathrm{Ca}(\mathrm{COOH})_{2}-\mathrm{B}$ & $\mathrm{Ca}(\mathrm{COOH})_{2}-\mathrm{C}$ & $\mathrm{CaSO}_{4}$-A & $\mathrm{CaCl}_{2}-\mathrm{A}$ & $\mathrm{CaCl}_{2}$ & $\mathrm{Ca}\left(\mathrm{NO}_{3}\right)_{2}$ \\
\hline \multicolumn{8}{|c|}{ Dry weight of shoot $(\mathrm{mg})^{\mathrm{z}}$} \\
\hline 0 & $244 \mathrm{a}$ & $244 \mathrm{a}$ & $244 \mathrm{a}$ & 244 a & 244 a & $244 \mathrm{a}$ & $244 \mathrm{a}$ \\
\hline 0.4 & $253 \mathrm{a}$ & $257 \mathrm{a}$ & $251 \mathrm{a}$ & $251 \mathrm{a}$ & $240 \mathrm{a}$ & 249 a & $252 \mathrm{a}$ \\
\hline 4 & $273 \mathrm{~b}$ & $290 \mathrm{~b}$ & $339 \mathrm{~b}$ & $243 \mathrm{a}$ & $279 \mathrm{~b}$ & $250 \mathrm{a}$ & $245 \mathrm{a}$ \\
\hline 10 & $314 \mathrm{c}$ & $299 \mathrm{c}$ & $320 \mathrm{~b}$ & $310 \mathrm{~b}$ & $270 \mathrm{~b}$ & $233 \mathrm{a}$ & 239 a \\
\hline 20 & $301 \mathrm{c}$ & $317 \mathrm{c}$ & $327 \mathrm{~b}$ & $310 \mathrm{~b}$ & $304 \mathrm{c}$ & $253 \mathrm{a}$ & 247 a \\
\hline \multicolumn{8}{|c|}{ Calcium concentration of shoot $(\% \text { dry weight })^{z}$} \\
\hline 0 & $0.153 \mathrm{a}$ & $0.153 \mathrm{a}$ & $0.153 \mathrm{a}$ & $0.153 \mathrm{a}$ & $0.153 \mathrm{a}$ & $0.153 \mathrm{a}$ & $0.153 \mathrm{a}$ \\
\hline 0.4 & $0.262 \mathrm{~b}$ & $0.232 \mathrm{~b}$ & $0.336 \mathrm{~b}$ & $0.201 \mathrm{~b}$ & $0.231 \mathrm{~b}$ & $0.199 \mathrm{~b}$ & $0.200 \mathrm{~b}$ \\
\hline 4 & $0.285 \mathrm{~b}$ & $0.324 \mathrm{c}$ & $0.332 \mathrm{~b}$ & $0.295 \mathrm{c}$ & $0.350 \mathrm{c}$ & $0.275 \mathrm{c}$ & $0.362 \mathrm{c}$ \\
\hline 10 & $0.349 \mathrm{c}$ & $0.370 \mathrm{~d}$ & $0.345 \mathrm{~b}$ & $0.334 \mathrm{~d}$ & $0.462 \mathrm{~d}$ & $0.463 \mathrm{~d}$ & $0.642 \mathrm{~d}$ \\
\hline 20 & $0.366 \mathrm{c}$ & $0.456 \mathrm{e}$ & $0.333 \mathrm{~b}$ & $0.392 \mathrm{e}$ & $0.487 \mathrm{e}$ & $0.532 \mathrm{e}$ & $0.767 \mathrm{e}$ \\
\hline
\end{tabular}

${ }^{y} \mathrm{Ca}(\mathrm{COOH})_{2}-\mathrm{A}, \mathrm{Ca}(\mathrm{COOH})_{2}-\mathrm{B}, \mathrm{Ca}(\mathrm{COOH})_{2}-\mathrm{C}, \mathrm{CaSO}_{4}-\mathrm{A}$, and $\mathrm{CaCl}_{2}-\mathrm{A}$ indicate $99.8 \% \mathrm{Ca}(\mathrm{COOH})_{2}+0.2 \%$ water, $90 \% \mathrm{Ca}(\mathrm{COOH})_{2}+10 \%$ calcium lignine sulfonate, $90 \% \mathrm{Ca}(\mathrm{COOH})_{2}+10 \% \mathrm{~B}_{2} \mathrm{O}_{5}, 57 \% \mathrm{CaSO}_{4}+27 \% \mathrm{CaO}$, and $72 \% \mathrm{CaCl}_{2}$, respectively.

${ }^{\mathrm{z}}$ Different letters in a column denote significant differences according to ANOVA and least significant difference $(P<0.05)$. 


\section{DISCUSSION}

Several studies have reported that calcium applications can suppress diseases caused by several pathogens $(4,6,35,40)$. However, few laboratory or field research findings are available concerning the application of calcium compounds for the management of Phytophthora stem rot on soybean.

In the present study, the five calcium compounds $\mathrm{Ca}(\mathrm{COOH})_{2}-\mathrm{A}, \mathrm{Ca}(\mathrm{COOH})_{2}-$ $\mathrm{B}, \mathrm{Ca}(\mathrm{COOH})_{2}-\mathrm{C}, \mathrm{CaSO}_{4}-\mathrm{A}$, and $\mathrm{CaCl}_{2}-\mathrm{A}$ were selected because of their high levels (57 to $98 \%$ ) of calcium as suitable treatments for reducing disease.

In order to evaluate the effects of several calcium treatments on Phytophthora stem rot disease suppression, this study first used the modified agar medium inoculation method $(27,28)$. This method was used because of the possible effect of some inorganic elements and varying $\mathrm{pH}$ differences, which should be eliminated or minimized; some inorganic elements have suppressive effects on several pathogens $(10,18)$. Results in this laboratory study using test bottles indicate that all seven calcium compounds suppressed incidence of disease caused by $P$. sojae in soybean cv. Chusei-Hikarikuro $(P<0.05)$, and markedly affected resistance to pathogens.

$\mathrm{Ca}(\mathrm{COOH})_{2}-\mathrm{A}, \quad \mathrm{Ca}(\mathrm{COOH})_{2}-\mathrm{B}, \quad$ and $\mathrm{Ca}(\mathrm{COOH})_{2}-\mathrm{C}$ decreased incidence of disease by 1.4 to $62.9 \%$. This is the first study to show that the application of $\mathrm{Ca}(\mathrm{COOH})_{2}$ has a suppressive effect on Phytophthora stem rot disease. There are only a few studies that address the potential for disease reduction using calcium formate $(1,4,21) . \mathrm{CaSO}_{4}$-A was also effective in reducing the disease by 14.3 to $25.4 \%$. It was reported that $\mathrm{CaSO}_{4} \cdot 2 \mathrm{H}_{2} \mathrm{O}$ (gypsum) decreased the incidence of Phytophthora root rot of avocado, caused by Phytophthora cinnamomi (19). Gypsum application suppressed Phytophthora root rot, caused by Phytophthora fragariae var. rubi, and increased survival, growth, and yield of raspberries in sites where the pathogen is present (17). $\mathrm{CaCl}_{2}$ - $\mathrm{A}$ had a suppressive effect on Phytophthora stem rot disease; the incidence of disease ranged from 17.9 to $56.3 \%$. The application of $\mathrm{CaCl}_{2}$ and $\mathrm{Ca}\left(\mathrm{NO}_{3}\right)_{2}$ reduced Phytophthora stem rot disease on soybean, and supports the results of a previous study (27). These results indicate that more than $4 \mathrm{mM}$ $\mathrm{Ca}(\mathrm{COOH})_{2}$ was most effective for reducing disease incidence compared with the other commercial calcium compounds used in this study.

It was recently stated that some inorganic elements could reduce fungal infection by directly inhibiting fungal growth $(3,4,22,27,28,40)$. To investigate this effect, the growth rates of PJ-H30 (race E) on PDA containing several levels of seven calcium compounds were examined. Although mycelium growth of $\mathrm{PJ}-\mathrm{H} 30$ was affected by the calcium concentration, no significant relationship was observed between inhibition of the fungal growth of the isolate (7 days after incubation) and disease reduction (7 days after inoculation). Contrary to expectations, mycelium growth of PJ-H30 was enhanced slightly by the application of 0.4 to $4 \mathrm{mM}$ $\mathrm{Ca}(\mathrm{COOH})_{2}-\mathrm{A}, \mathrm{Ca}(\mathrm{COOH})_{2}-\mathrm{B}$, and $\mathrm{CaCl}_{2}$, $0.4 \mathrm{mM} \mathrm{Ca}(\mathrm{COOH})_{2}-\mathrm{C}, 4 \mathrm{mM} \mathrm{CaCl} 2-\mathrm{A}$, 0.4 to $10 \mathrm{mM} \mathrm{Ca}\left(\mathrm{NO}_{3}\right)_{2}$, and 0.4 to $20 \mathrm{mM}$ $\mathrm{CaSO}_{4}-\mathrm{A}(P<0.05) . \mathrm{Ca}(\mathrm{COOH})_{2}(600 \mathrm{mg}$ liter $\left.^{-1} ; 4.6 \mathrm{mM}\right)$ did not reduce growth of Monilinia fructicola (4). It was reported that $1,000 \mathrm{mg}$ of calcium (calcium chloride) enhanced the growth of Botryosphaeria dothidea (3). However, incidence of disease was reduced significantly by the same concentration of seven calcium nutri- ents in comparison with controls $(P<$ $0.05)$. This study supports previous findings (27).

In contrast to the above, more than $10 \mathrm{mM} \mathrm{Ca}(\mathrm{COOH})_{2}-\mathrm{A}, \mathrm{Ca}(\mathrm{COOH})_{2}-\mathrm{B}$, $\mathrm{Ca}(\mathrm{COOH})_{2}-\mathrm{C}, \mathrm{CaCl}_{2}-\mathrm{A}$, and $20 \mathrm{mM}$ $\mathrm{CaCl}_{2}$ reduced mycelial growth, suggesting that $\mathrm{Ca}(\mathrm{COOH})_{2}$ and $\mathrm{CaCl}_{2}$ involve a factor(s) for suppressing fungal metabolism. This is the first study of fungal growth reduction with high concentrations of $\mathrm{Ca}(\mathrm{COOH})_{2}$. There was a significant relationship between mycelium growth and disease suppression ( 7 days after inoculation) when 10 to $20 \mathrm{mM} \mathrm{Ca}(\mathrm{COOH})_{2}-\mathrm{A}$, $\mathrm{Ca}(\mathrm{COOH})_{2}-\mathrm{B}, \mathrm{Ca}(\mathrm{COOH})_{2}-\mathrm{C}$, and $\mathrm{CaCl}_{2}-$ A were applied. This result was due to multiple effects of direct suppression on

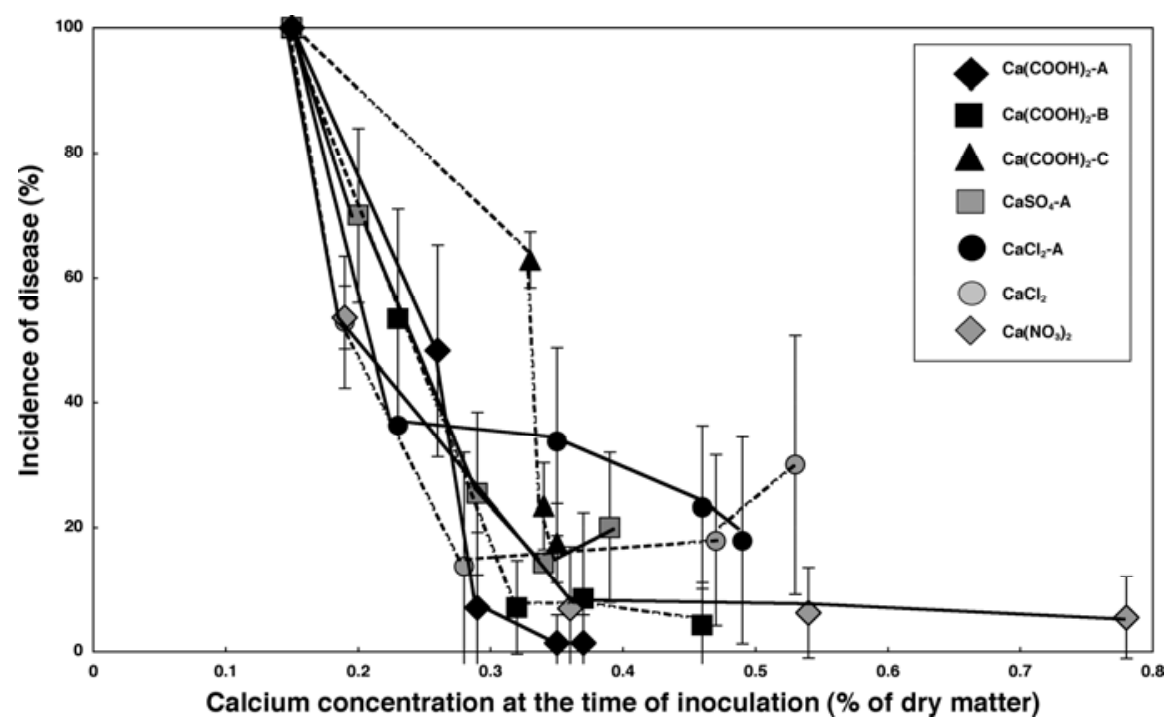

Fig. 3. Relationship between calcium content in shoots and incidence of disease on black soybeans 20 days after inoculation. $\mathrm{Ca}(\mathrm{COOH})_{2}-\mathrm{A}, \mathrm{Ca}(\mathrm{COOH})_{2}-\mathrm{B}, \mathrm{Ca}(\mathrm{COOH})_{2}-\mathrm{C}, \mathrm{CaSO}_{4}-\mathrm{A}$, and $\mathrm{CaCl}_{2}-\mathrm{A}$ indicate $99.8 \% \mathrm{Ca}(\mathrm{COOH})_{2}+0.2 \%$ water, $90 \% \mathrm{Ca}(\mathrm{COOH})_{2}+10 \%$ calcium lignine sulfonate, $90 \%$ $\mathrm{Ca}(\mathrm{COOH})_{2}+10 \% \mathrm{~B}_{2} \mathrm{O}_{5}, 57 \% \mathrm{CaSO}_{4}+27 \% \mathrm{CaO}$, and $72 \% \mathrm{CaCl}_{2}$, respectively. Bars indicate standard error of the mean.

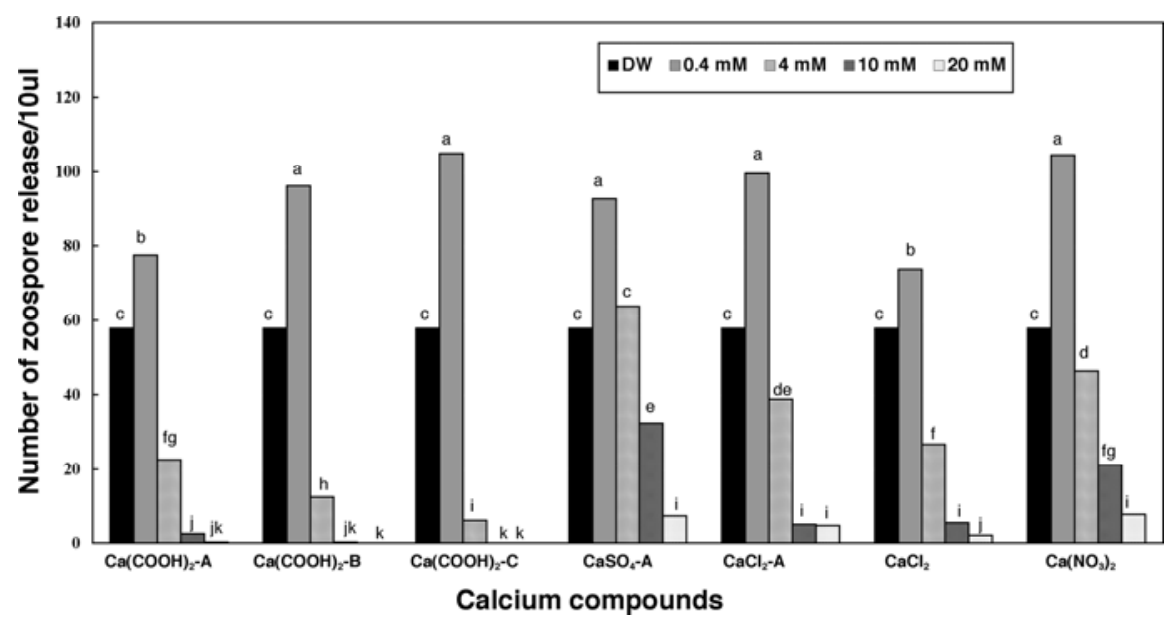

Fig. 4. Effect of various concentrations $(0,0.4,4,10$, and $20 \mathrm{mM})$ of seven calcium compounds on zoospore release from Phytophthora sojae isolate $\mathrm{PJ}-\mathrm{H} 30$ on lima bean. $\mathrm{Ca}(\mathrm{COOH})_{2}-\mathrm{A}, \mathrm{Ca}(\mathrm{COOH})_{2^{-}}$ $\mathrm{B}, \mathrm{Ca}(\mathrm{COOH})_{2}-\mathrm{C}, \mathrm{CaSO}_{4}-\mathrm{A}$, and $\mathrm{CaCl}_{2}-\mathrm{A}$ indicate $99.8 \% \mathrm{Ca}(\mathrm{COOH})_{2}+0.2 \%$ water, $90 \%$ $\mathrm{Ca}(\mathrm{COOH})_{2}+10 \%$ calcium lignine sulfonate, $90 \% \mathrm{Ca}(\mathrm{COOH})_{2}+10 \% \mathrm{~B}_{2} \mathrm{O}_{5}, 57 \% \mathrm{CaSO}_{4}+27 \%$ $\mathrm{CaO}$, and $72 \% \mathrm{CaCl}_{2}$, respectively. Incidence of disease at $20 \mathrm{mM} \mathrm{Ca}(\mathrm{COOH})_{2}-\mathrm{C}$ was not shown, because this concentration was phytotoxic to soybean plants. Different letters denote significant differences according to ANOVA and least significant difference $(P<0.05)$. 
mycelium growth in combination with the response of the host plant tissue to those nutrients. These results show that application of calcium nutrients inhibits fungal growth at high concentration levels except for $\mathrm{CaSO}_{4}-\mathrm{A}(P<0.05)$.

Moreover, the release of zoospores from the isolate on PDA did not occur during experiments (data not shown) or in the zoospore test when $P$. sojae mycelium cultured on PDA was used for the disease experiments with agar medium inoculation. Some inorganic elements affect disease potential more than inoculum potential, and some nutrients may decrease disease even though the population of a pathogen is increased (11). It was reported that good calcium fertility is associated with strong cell walls that enhance disease resistance and the ability of the crop to maintain firm tissues (18). In view of these results, the disease reduction shown in the present study was predominately due to the response of the host tissue to calcium rather than direct hyphal growth inhibition of the pathogen by the calcium compounds.

Previous studies have shown that disease suppression was due to the increased resistance to the pathogen by increased levels of calcium in the cell wall region (6). We hypothesized that if the concentration of calcium in plants could be increased by the application of calcium "by the time of inoculation", that such applications may improve the resistance of soybean to Phytophthora stem rot. Our results demonstrated that calcium concentrations in plants of cv. Chusei-Hikarikuro increased "before inoculation" due to the application of calcium. This result indicated that increased calcium concentrations in soybean plants were associated with disease reduction. Our results support the assertion that soybean seedlings acquired resistance to the pathogen as the calcium content in the plant was increased prior to inoculation.

Further research is needed to identify the optimal concentrations of calcium amendments for disease management. High levels of $\mathrm{Ca}(\mathrm{COOH})_{2}-\mathrm{C}$ caused phytotoxicity on seedlings cv. ChuseiHikarikuro. Incidence of disease slightly increased when $10 \mathrm{mM} \mathrm{Ca}(\mathrm{COOH})_{2}-\mathrm{C}$ (containing 90\% calcium formate and $10 \%$ boric acid) was applied, compared with the plants amended with the same concentrations of $\mathrm{Ca}(\mathrm{COOH})_{2}-\mathrm{A} . \mathrm{Ca}(\mathrm{COOH})_{2}-\mathrm{A}$ (containing $99.8 \%$ calcium formate) did not cause phytotoxicity. The incidence of disease slightly increased when the amount of calcium applied as $10 \mathrm{mM} \mathrm{CaSO} \mathrm{C}_{4}-\mathrm{A}$ or $4 \mathrm{mM} \mathrm{CaCl} 2$ was more than $0.334 \%$ $\left(\mathrm{CaSO}_{4}-\mathrm{A}\right)$ or $0.275 \%\left(\mathrm{CaCl}_{2}\right)$ of the shoot dry weight. This trend also was found in a previous study of $\mathrm{CaCl}_{2}$ application (27,28). Therefore, the rates of $\mathrm{Ca}(\mathrm{COOH})_{2}-\mathrm{C}, \mathrm{CaSO}_{4}-\mathrm{A}$, and $\mathrm{CaCl}_{2}$ applications need to be further evaluated to reduce the risks of phytotoxicity or disease enhancement in soybean.

The effect of seven calcium compounds on zoospore release from $P$. sojae on LBA medium was investigated for an evaluation of the potential applicability of our in vitro results to field situations. The zoospore swimming speed of PJ-H30 was reduced dramatically by high levels of seven calcium compounds (T. Sugimoto, unpublished results). It was also reported previously that the application of a high concentration $(30 \mathrm{mM})$ of $\mathrm{CaCl}_{2}$ or $\mathrm{Ca}\left(\mathrm{NO}_{3}\right)_{2}$ inhibited zoospore release from two P. sojae isolates (27). Increasing concentration of calcium correlated negatively with the release of zoospore from Phytophthora spp. (16). High levels of extracellular calcium can rapidly immobilize Phytophthora zoospores (5), induce zoospore cysts to germinate without a host or nutrient trigger, and suppress the production of further zoospores (36). High external concentrations of calcium salts reduced zoospore swimming speed of Phytophthora spp.; $\mathrm{Ca}^{2+}$ amendments interfere with Phytophthora parasitica zoospore biology at multiple stages (37). Zoospore production and colony-forming units of Phytophthora cinnamomi were reduced in soil amended with calcium sulfate, calcium nitrate, or calcium carbonate (20). These results may strengthen the possibility of applying calcium solutions to reduce the incidence of disease in practical agricultural situations.

In contrast to the above, the application of $0.4 \mathrm{mM} \mathrm{Ca}(\mathrm{COOH})_{2}-\mathrm{A}, \mathrm{Ca}(\mathrm{COOH})_{2}-\mathrm{B}$, $\mathrm{Ca}(\mathrm{COOH})_{2}-\mathrm{C}, \mathrm{CaCl}_{2}-\mathrm{A}$, and 0.4 to $4 \mathrm{mM}$ of $\mathrm{CaSO}_{4}$ - $\mathrm{A}$ enhanced zoospore release from isolate PJ-H30. This finding also was observed in previous reports; the presence of 0.1 to $2.5 \mathrm{mM} \mathrm{CaCl}$ and $0.4 \mathrm{mM}$
$\mathrm{Ca}\left(\mathrm{NO}_{3}\right)_{2}$ significantly induced zoospore release $(27,28)$. A minimum concentration of calcium is necessary for the production of zoosporangia or zoospore release by Phytophthora spp. $(9,23,37)$. It is therefore necessary to examine effective levels of calcium nutrients for disease suppression in the field.

A seedling assay using vermiculite was performed in an effort to confirm that calcium is an effective amendment for reducing Phytophthora stem rot disease. $\mathrm{Ca}(\mathrm{COOH})_{2}-\mathrm{A}$ was selected from five calcium products. Experimental results of the seedling tray bioassay almost paralleled those of the agar medium inoculations. It was concluded that disease reduction was due to the multiple effects of direct suppression on zoospore release and fungal growth in combination with the response of the host plant tissue to $\mathrm{Ca}(\mathrm{COOH})_{2}$-A. However, the suppressive effect of calcium application on the seedling tray test was slightly reduced in comparison to the agar medium experiments. This might have been caused by the buffering effect of vermiculite, and antagonistic or synergistic activities between calcium and other inorganic elements (16). Highpotassium and low-calcium conditions increased disease caused by $P$. parasitica (10). The level of potassium in plants depends on the availability of calcium and magnesium. Potassium availability is enhanced by calcium (18). Balanced nutrients are an important factor in plant resistance to disease.

The cellular mechanisms involved in disease reduction need further research. It was reported that several factors influence the effectiveness of calcium fertilizer in reducing the incidence of disease (22). It has been noted that the $\mathrm{Ca}^{2+}$ ion signal is one of the earliest events in challenged cells, and the signal is essential for the activation of plant defense responses such as phytoalexin biosynthesis, induction of defense-related genes, and hypersensitive cell death (15). Examination of gene expression related to plant defense reaction and signaling in Phytophthora stem rot on soybean in response to the application of calcium could answer this question.

In conclusion, this study showed that applications of seven calcium compounds greatly influenced disease reduction of

Table 3. Effect of $\mathrm{Ca}(\mathrm{COOH})_{2}-\mathrm{A}$ application on the incidence of disease and plant height in black soybean plants

\begin{tabular}{lccccc}
\hline \multirow{2}{*}{$\begin{array}{l}\text { Concentration } \\
(\mathbf{m M})\end{array}$} & \multicolumn{2}{c}{ Incidence of disease } & \multicolumn{2}{c}{ Plant height $^{\mathbf{y}}$} \\
\cline { 2 - 3 } \cline { 5 - 6 } \cline { 5 - 6 } & $\mathbf{7}$ days after inoculation & $\mathbf{2 0}$ days after inoculation & & At time of inoculation & $\mathbf{7}$ days after inoculation \\
\hline 0 & $49.4 \mathrm{a}^{\mathrm{z}}$ & $12.7 \mathrm{~b}$ & $68.0 \mathrm{a}$ & $9.8 \mathrm{a}$ & $15.7 \mathrm{a}$ \\
4 & $5.0 \mathrm{c}$ & $16.9 \mathrm{~b}$ & $10.1 \mathrm{a}$ & $16.8 \mathrm{a}$ \\
10 & $1.9 \mathrm{~d}$ & $5.8 \mathrm{~d}$ & $11.3 \mathrm{a}$ & $18.7 \mathrm{~b}$ \\
20 & $4.1 \mathrm{c}$ & $7.4 \mathrm{~d}$ & $1.6 \mathrm{a}$ & $18.5 \mathrm{~b}$ \\
\hline
\end{tabular}

${ }^{y}$ Plant height was measured 10 days after the sowing of seeds (at the time of inoculation) and 7 days after inoculation from the ground level to the top of the plant.

${ }^{\text {z }}$ Different letters in a column denote significant differences according to ANOVA and least significant difference $(P<0.05)$. 
Phytophthora stem rot in soybean. The suppressive effect was observed when unamended vermiculite was irrigated with $\mathrm{Ca}(\mathrm{COOH})_{2}-\mathrm{A}$. The results suggest that this effect could be mediated by a response of the host tissue to increased calcium directly, and possibly by a direct inhibition of fungal growth (at high levels of calcium). The applications of calcium solutions (more than $10 \mathrm{mM}$ ) may be effective for disease management of Phytophthora stem rot in the field. The findings of this study may lead to effective field strategies for the management of Phytophthora stem rot in soybean.

\section{ACKNOWLEDGMENTS}

We thank Cindi Lett for reviewing this manuscript; Kiyotomo Futai, Toshiharu Onishi, and Eiji Hinomoto for collecting the diseased plants; and Satoshi Koike (Tokachi Federation of Agricultural Cooperatives) for providing seeds of cv. ChuseiHikarikuro. This work was supported by a grant from the Ministry of Agriculture, Forestry and Fisheries of Japan (Genomics for Agricultural Innovation, DD-3113), and by a grant from the Hyogo Prefectural Government (Overseas training programs for young staff, 2008).

\section{LITERATURE CITED}

1. Adaskaveg, J. E., Ogawa, J. M., and Feliciano, A. J. 1992. Comparisons of calcium-based and film-forming materials for control of brown rot of peach caused by Monilinia fructicola. (Abstr.) Phytopathology 82:1158.

2. Anderson, T. R., and Buzzell, R. I. 1982. Efficacy of metalaxyl in controlling Phytophthora root and stalk rot of soybean cultivars differing in field resistance. Plant Dis. 66:1144-1145

3. Biggs, A. R. 2004. Effect of inoculum concentration and calcium salts on infection of apple fruit by Botryosphaeria dothidea. Plant Dis. 88:147-151.

4. Biggs, A. R., El-Kholi, M. M., EI-Neshawy, S., and Nickerson, R. 1997. Effects of calcium salts on growth, polygalacturonase activity, and infection of peach fruit by Monilinia fructicola. Plant Dis. 81:399-403.

5. Byrt, P. N., Irving, H. R., and Grant, B. R. 1982. The effect of cations on zoospores of the fungus Phytophthora cinnamomi. J. Gen. Microbiol. 128:1189-1198.

6. Conway, W. S., Sams, C. E., Mcguire, R. G., and Kelman, A. 1992. Calcium treatment of apples and potatoes to reduce post-harvest decay. Plant Dis. 76:329-334

7. Dorrance, A. E., McClure, S. A., and St. Martin, S. K. 2003. Effect of partial resistance on Phytophthora stem rot incidence and yield of soybean in Ohio. Plant Dis. 87:308-312.

8. Grau, C. R., Dorrance, A. E., Bond, J., and Russin, J. S. 2004. Fungal Diseases. Pages 679-763 in: Soybeans: Improvement, Production and Uses. 3rd ed. Agronomy Monogr. H. R. Boerma and J. E. Specht, eds. American Society of Agronomy, Madison, WI.

9. Halsall, D. M., and Forrester, R. I. 1977. Effects of certain cation on the formation and in- fectivity of Phytophthora zoospores: I. Effect of calcium, magnesium, potassium and iron ions. Can. J. Microbiol. 23:994-1001.

10. Huber, D. M. 1981. The use of fertilizers and organic amendments in the control of plant disease. Pages 357-394 in: CRC Handbook of Pest Management of Agriculture. Vol. 1. D. Pimentel, eds. CRC Press, Boca Raton, FL.

11. Huber, D. M., and Watson, R. D. 1970. Effect of organic amendment on soilborne diseases. Phytopathology 60:22-26.

12. Hunger, R. M., Hamm, P. B., Horner, C. E., and Hansen, E. M. 1982. Tolerance of Phytophthora megasperma isolates to metalaxyl. Plant Dis. 66:645-649.

13. Jackson, T. A., Kirkpatrick, T. L., and Rupe, J. C. 2004. Races of Phytophthora sojae in Arkansas soybean fields and their effects on commonly grown soybean cultivars. Plant Dis. 88:345-351.

14. Kaufmann, M. J., and Gerdemann, J. W. 1958. Root and stem rot of soybean caused by Phytophthora sojae n. sp. Phytopathology 48:201208.

15. Knight, M. R., Cambel, A. K., Smith, S. M., and Trewavas, A. J. 1991. Transgenic plant aequorin reports the effects of touch and cold shock and elicitors on cytoplasmic calcium. Nature 352:524-526.

16. Koohakan, P., Ikeda, H., Jaenaksorn, T., Tojo, M., and Kusakari, S. 2002. Effects of inorganic elements on the in-vitro growth of Pythium aphanidermatatum (Edson) Fitzp. Microbes Environ. 17:91-97.

17. Maloney, K., Pritts, M., Wilcox, W., and Kelly, M. J. 2005. Suppression of Phytophthora root rot in red raspberries with cultural practices and soil amendments. HortScience 40:17901795.

18. Marschner, H. 1995. Relationship between mineral nutrition and plant disease and pests. Pages 436-460 in: Mineral Nutrition of Higher Plants. 2nd ed. Academic Press, London.

19. Messenger, B. J., Menge, J. A., and Pond, E. 1996. Effect of gypsum soil amendments on avocado root rot. (Abstr.) Phytopathology 86:S30.

20. Messenger, B. J., Menge, J. A., and Pond, E. 2000. Effects of gypsum on zoospores and sporangia of Phytophthora cinnamomi in field soil. Plant Dis. 84:617-621.

21. Punja, Z. K., and Gaye, M. M. 1993. Influence of postharvest handling practices and dip treatment on development of black root rot on fresh market carrots. Plant Dis. 77:989-995.

22. Rahman, M., and Punja, Z. K. 2007. Calcium and Plant Disease. Pages 79-93 in: Mineral Nutrition and Plant Disease. L. E. Datnoff, W. H. Elmer, and D. M. Huber, eds. American Phytopathological Society, St. Paul, MN.

23. Sato, N. 1994. Effect of some inorganic salts and hydrogen ion concentration on indirect germination of the sporangia of Phytophthora infestans. Ann. Phytopathol. Soc. Jpn. 60:441447.

24. Schmitthenner, A. F. 1985. Problems and progress in control of Phytophthora root rot of soybean. Plant Dis. 69:362-368.

25. Schmitthenner, A. F. 1999. Phytophthora rot of soybean. Pages 39-42 in: Compendium of Soybean Diseases. 4th ed. G. L. Hartman, J. B. Sinclair, and J. C. Rupe, eds. American Phyto- pathological Society, St. Paul, MN.

26. Slade, S. J., and Pegg, G. F. 1993. The effect of silver and other metal ions on the in vitro growth of root-rotting Phytophthora and other fungus species. Ann. Appl. Biol. 122:233-251.

27. Sugimoto, T., Aino, M., Sugimoto, M., and Watanabe, K. 2005. Reduction of Phytophthora stem rot disease on soybeans by the application of $\mathrm{CaCl}_{2}$ and $\mathrm{Ca}\left(\mathrm{NO}_{3}\right)_{2}$. J. Phytopathol. 153:536-543.

28. Sugimoto, T., Watanabe, K., Yoshida, S., Aino, M., Matsuyama, M., Maekawa, K., and Irie, K. 2007. The effects of inorganic elements on the reduction of Phytophthora stem rot disease of soybean, the growth rate and zoospore release of Phytophthora sojae. J. Phytopathol. 155:97-107.

29. Sugimoto, T., Yoshida, S., Aino, M., Ohnishi, T., and Shiwaku, K. 2003. Development of the agar medium inoculation method for the pathogenic test of Phytophthora sojae. Proc. Kansai Plant Prot. 45:93-96 (In Japanese with English summary).

30. Sugimoto, T., Yoshida, S., Aino, M., Watanabe, K., Shiwaku, K., and Sugimoto, M. 2006. Race distribution of Phytophthora sojae on soybean in Hyogo, Japan. J. Gen. Plant Pathol. 72:92 97.

31. Sugimoto, T., Yoshida, S., Watanabe, K. Aino, M., Kanto, T., Maekawa, K., and Irie, K. 2008. Identification of SSR markers linked to the Phytophthora resistance gene Rpsl-d in soybean. Plant Breed. 127:154-159.

32. Takahashi, R., Ohmori, R., Kiyose, C., Momiyama, Y., Ohsuzu, F., and Kondo, K. 2005. Antioxidant activities of black and yellow soybeans against low density lipoprotein oxidation. J. Agric. Food Chem. 53:4578-4583.

33. Toppe, B., and Thinggaard, K. 1998. Prevention of Phytophthora root rot in Gerbera by increasing copper ion concentration in the nutrient solution. Eur. J. Plant Pathol. 104:359-366.

34. Tsuchiya, S., Kodama, F., Akai, J., and Matsumura, Y. 1978. Occurrence of soybean stem rot caused by Phytophthora sojae megasperma var. sojae Hildebrand in Hokkaido. (Abstr. in Japanese) Jpn. J. Phytopathol. 44:351.

35. Volpin, H., and Elad, Y. 1991. Influence of calcium nutrition on susceptibility of rose flowers to Botrytis blight. Phytopathology 81:1390-1394.

36. von Broembsen, S. L., and Deacon, J. W. 1996. Effects of calcium on germination and further zoospore release from zoospore cysts of Phytophthora parasitica. Mycol. Res. 100:14981504.

37. von Broembsen, S. L., and Deacon, J. W. 1997. Calcium interference with zoospore biology and infectivity of Phytophthora parasitica in nutrient irrigation solution. Phytopathology 87:522-528.

38. Workneh, F., Yang, X. B., and Tylka, G. L. 1998. Effect of tillage practices on vertical distribution of Phytophthora sojae. Plant Dis. 82:1258-1263.

39. Wrather, J. A., and Koenning, S. R. 2006 Estimates of disease effects on soybean yields in the United States 2003 to 2005. J. Nematol. 38:173-180

40. Yamazaki, H., and Hoshina, T. 1995. Calcium nutrition affects resistance of tomato seedlings to bacterial wilt. HortScience 30:91-93. 